\title{
Using consumer-generated content for competitive advantage - Interview with John Hingley of Andiamo Systems
}

\begin{abstract}
John Hingley
is the CEO and Founder of Andiamo Systems, a leading word-of-mouth and social media analysis provider to businesses of all sizes. John brings over 20 years of experience leading direct, brand and internet marketing programs for leading companies in technology, media and online retail industries. John served as Chief Operating Officer for wine.com, the world's largest online wine retailer. Before to wine.com, John was General Manager of Yaga, one of the first peer-to-peer content distribution networks. He was also Vice President of Direct Response and Ecommerce for The Learning Company and Mattel Interactive. Prior to starting Andiamo Systems in 2006, John was the Founder of Crush Direct, a boutique brand and direct marketing agency for the wine and spirits industries. It was his experience launching social media programs at Crush that motivated him to start a business to monitor and measure the impact consumers have on brand perception and purchase intent. Hence, Andiamo Systems was born. John holds a degree from the University of Oregon in Finance and Marketing. John is also a board member of VerticalResponse, a leading self-service direct marketing provider to over 40,000 businesses worldwide and an Inc. 500 fastest-growing company.
\end{abstract}

Keywords: social media, dam analytics, Web 2.0, Agency DAM, ugc, brand buzz

Abstract Social media is changing the way today's companies do business. Savvy businesses - and their agencies - are now able to use online consumer-generated content in the form of blogs, forums and social networks to their competitive advantage. The ease at which consumers can express their opinions online provides businesses continual and real-time insights they can use to develop more effective products, services, and marketing and advertising strategies.

Journal of Digital Asset Management (2008) 4, 158-170. doi:10.1057/dam.2008.19

John Hingley

Andiamo Systems, Inc.,

501 2nd Street, Suite 700

San Francisco, CA 94107, USA

Tel: 4158190489 E-mail: john@andiamosystems. com
MM: John, if you would, give us a little of your background. A little bit of your history and some on your company.

JH: Sure thing. I've been involved in direct marketing and business development in the technology and consumer packaged goods industry for the past 25 years or so. I've seen a lot from both the $\mathrm{B} 2 \mathrm{~B}$ and $\mathrm{B} 2 \mathrm{C}$ side of things.

Most recently, before starting Andiamo Systems, I started a boutique advertising agency for the wine and spirits industry called 'Crush Direct' Prior to that, I was the COO at wine.com, which was a very interesting turnaround time for that company, as it was going through a new iteration of its business model and a [D] series of financing.

I was there for two years, and we actually brought that company to its first profitable quarter ever during that time period. That was in 2003.

Before that, I was a founding member of a company called 'Yaga.' That was a very interesting company. This was born just after the dot-bomb - 2001 - when it was very, very hard to get financing. This was a P2P content distribution network. That means they had the ability to transfer big files efficiently across the Internet. Those could be perhaps movies or movie clips moving across the Internet, using a peer-based model instead of a single-server model.

We were marketing to folks like Warner Brothers, Paramount Picture and Disney as a good alternative way to distribute film.

It ended up that we were a bit early on for the industry. Overall, we had a hard time figuring out the business model in a way that made sense and made it a real, thriving business. We did end up selling that company to another player in the field called BitPass.

Just before that, my wife and I both went through the San Francisco-based dot-com and dot-bomb. I was at The Learning Company, which Mattel bought out for about $\$ 3$.8bn. 


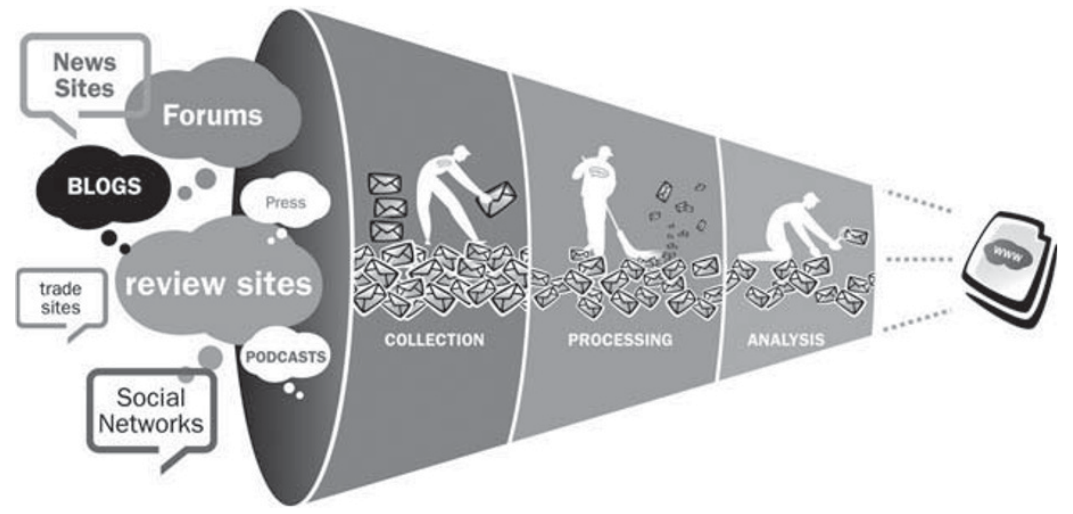

Figure 1: Social media analysis. The 4-step process of social media analysis: multi-source data collection; processing and removal of splog and false matches; advanced analytics for semantic analysis and influence ratings; and on-demand web-based reporting

We called my division Mattel Interactive. That was a way for them to get more high-tech. Around the same time, the company my wife worked for, xoom.com, went public.

So knowing that it's pretty rare for a working couple to ever have the opportunity to take a break at the same time, we went for it. We moved to France for a light break but of course, we couldn't rest. About four months after we moved to France, we moved back to San Francisco and started up a company called VerticalResponse, which is now a leading e-mail service provider. Janine is the CEO and the driving force behind its success.

Then before that, there were many stints at both publishing, education and software companies, as well as my own company back in the early 1980s.

MM: It would be fair to say then, John, that you've made most of the mistakes that one could make.

JH: I learn something every day and make mistakes every day, I'm sure. But yes, I've been through the wringer with the good and bad times.

MM: That's a great context for then describing the launch of Andiamo Systems. So, what is Andiamo Systems about?

JH: Andiamo Systems is a social media measurement and analysis company. That means that we collect, process, analyze and then report on everything that people are saying about our clients' brands across the vast spectrum of online media, whether it's a customer talking about a wine they like or don't like on a blog, or someone else talking about what they think about the Blade Runner IV release on Blu-Ray on another forum. Or someone talking about my wife's company VerticalResponse on a message board.

We have the technology that captures and collects on a continual basis all of that information. We process out all of the splog and all of the irrelevant false-positive matches. Then, we run it through a set of algorithms with a layer of human review (Figure 1).

Then at the end of the process, we make very intuitive reports available to our business clients. This tells them how much is being said about them online, where it's coming from, and if it's mainstream media versus consumer-generated media. Whether it's blogs or forums. Whether it's message boards, social networks and the like.

Most importantly, we report on how much influence the people who are talking have over brand perception and purchase intent in that industry. And what the sentiment is - what the real consumer opinion is toward the brand and how it is trending over time. Both at the very granular level and overall. What the brand's health and reputation is for these brands online.

The genesis of this was something that was born out of real-life experience. At Crush Direct, we worked with a couple of new wind brands actually owned by large companies. One was owned by Fosters, the large Australian wine company. They came to us wanting help in launching a new wine called 'The Little Penguin' on a very, very tight budget. Basically zero budget. 
We did something that I think was clever, but also lucky. We decided to create a series of interactive web-based content promotions around these brands. We seeded blogs with little contests. We passed them along and got ready for the launch of this product, etc. We made it very interactive and very oriented toward two things: pass-alongs and signing up to receive more information about these brands.

Bottom line: both of these product launches were very, very successful. They far outpaced expectations. As a direct marketer, I always want to quantify everything I can. I went in knowing that half of our success was probably dumb luck. The other half was probably some fairly sharp things we did.

So, I started to go in and manually mine blogs and do blog searches and forum searches to see who was talking about these brands and what they were talking about. Who seemed to be a promoter? Who seemed to be a detractor? Who seemed to have a lot of influence and traffic to their website. I could then in turn take those successes and have a better chance of replicating those, going forward.

I found that, in addition to this exercise just being a mind-numbingly dull and tedious job, it's very error-prone to do it by pure human review. It's very expensive and not timely. It takes way too much time to go back and find all this information manually and then rate it on sentiment and speaker influence and the like so you actually get a timely report of what's going on with your brand online.

I did some market research - still without the thought of starting one of these companies myself. I just wanted help in an automated solution to gauge and measure social media. This is going back a few years - about three years, now.

The market was dominated by enterprise players with very prohibitively expensive solutions. Except for the top Fortune 500 companies. These are six-figure solutions - very much enterprise software. Not Software as a Service (SaaS).

MM: You're talking more like Autonomy and Fast and those kinds of things?

JH: As well as Nielsen BuzzMetrics, Umbria, Biz360 and some of the more new-age folks that have been around five years or so. That really attacked the problem from a human-scale perspective. A lot of hand holding. Not that much technology. Like I said - very, very geared toward just a fraction of the market.

One of them actually pitched one of my wine clients called 'The Little Penguin' after the success of the online launch. I sat in on this pitch and I thought it was a very well done business presentation. But at the end of the presentation they laid out a six-figure annual budget for what they wanted to do and provide to this wine brand. The six-figure budget for social media analysis was more than this person's marketing budget in a given year.

So that is where the market was four years ago. What I decided on the drive back from Napa to San Francisco was to go for it. To start my own company that provides social media analysis in a SaaS approach: very timely, affordable and intuitive. That means you don't need to be a market researcher to understand the information that we provide. We really aim to make our reporting as intuitive, actionable and easy to understand as possible.

Going on two and a half years ago, while still running Crush, I specced out the product and hired a great product manager and a good technical team to begin developing this product.

Two years later - going on five or six months ago - after two years of straight development - we were finally ready for a launch. We soft-launched in late 2007. So far, even with virtually zero advertising, we've gotten most of our customers by word-ofmouth. That's very powerful. We've seen just a huge market opportunity, and need for a product that fits this need for the mid-sized business. You're not going to get Bob's corner store paying us to see what people are saying about them online because frankly, people aren't saying anything.

This mid-size market is typically underserved, especially with new technology. You've got the big enterprise folks at the high end charging six figures and up for social media analysis. Then at the lower end, you've got free tools. I advocate that some folks who don't get much buzz currently should go ahead and use free tools such as Google Alerts.

But by the time you get any level of buzz and most of our customers use us to track their brand as well as two or three or four competing brands - that's just too much data to assimilate 
and act on, and frankly make sense of, in any type of reasonable time-frame.

MM: Let me set up a basic market requirement and have you address that.

One of the things that we've tracked now for quite some time has been what I'll call the implosion of the campaign. That is to say, campaigns as a practice and a mindset usually started with some big insight about an unserved market or an emerging market.

Out of this customer insights practice, or whatever companies had in terms of their market research activity, it then led to a formulation of a strategy.

The way that I define a strategy is it's simply a device or mechanism for marshaling available resources. So part of the strategy formation is this kind of quick-cycle iterative, "What's the opportunity? How do we unlock it? What are our strengths? What are our weaknesses? What's our go-to-market?"

Then in the course of a couple or several weeks or a month, it evolves into a marketing launch or a marketing platform and a set of creative briefs. These creative briefs go out to the appropriate creative partner. The direct-mail group. The online group. The interactive group. The promotions group. The in-store marketing group. The advertising guys and print guys. All of that.

They go off and do their things - which is really kind of a scheduling project-management review-and-approval, distribution process. Then it hits January. It'll be 21 June and we paint the town red. Right? We do our launch, we light it all up across all of our channels. All of the major customer touch points, so as to get a maximum kind of echo-effect in our market. So the outdoor billboards are harmonized with in-store messaging — the direct-mail and the telecenters are all spun up with the right scripts and so on.

The challenge that we've seen in that particular program is that first of all, customers aren't just sitting around waiting to have someone market to them. They're out there. Googling. They're surfing around. They're looking at stuff. They're actually taking the engagement to the marketer.

They're not just sitting around waiting to be marketed to. They're actually engaging marketers or potential marketers way before they've actually launched.
To your point, a lot of companies now today are doing a soft launch while they're getting their marketing communications and corporate storytelling act together. Meanwhile, there's all this activity in terms of social media, with the most viral and most explosive part of that being viral video and other forms of rich media sharing.

That has the net effect of forcing marketing strategists and marketing teams to think more in terms of an engagement strategy through a lifecycle of brand interactions, as opposed to a big-bang launch echo effect.

Does that more or less track with your experience as a leader out there or a pioneer, in terms of the marketing frontier? If not, how not?

JH: That does track with what I see and what I hear from our customers and other folks I speak with. The advent of social media and the ease with which people can publish their thoughts and opinions online. Then, the ease of which people can go and read all of this stuff and start to share their opinions - or at least become more insightful about what other consumers like themselves think - turns a lot of this traditional campaign planning on its ear.

Nielsen is one of the larger entrenched enterprise competitors. They're a great company. They did a study that showed $3 / 4$ of consumers rate word-of-mouth as the number 1 influencer of brand perception and purchase. So today's most savvy or advanced customers and their agencies are using tools like mine and others to help them determine not even what the campaign should be, but what the product or product features should be before developing them.

Then, doing more iterative mini-launches, whether it's on blogs or whether it's a viral video. We actually have a customer that dabbles in that area now and uses us to see what the comments on their videos are and what the count of viewership is. If the URL of that YouTube video gets passed along and who it gets passed to and then what the reaction to it is.

This paradigm shift is impacting marketers, I think, in a very positive way. It opens up a very rich and continually updated universe of unbiased consumer opinions and reviews (Figure 2). 


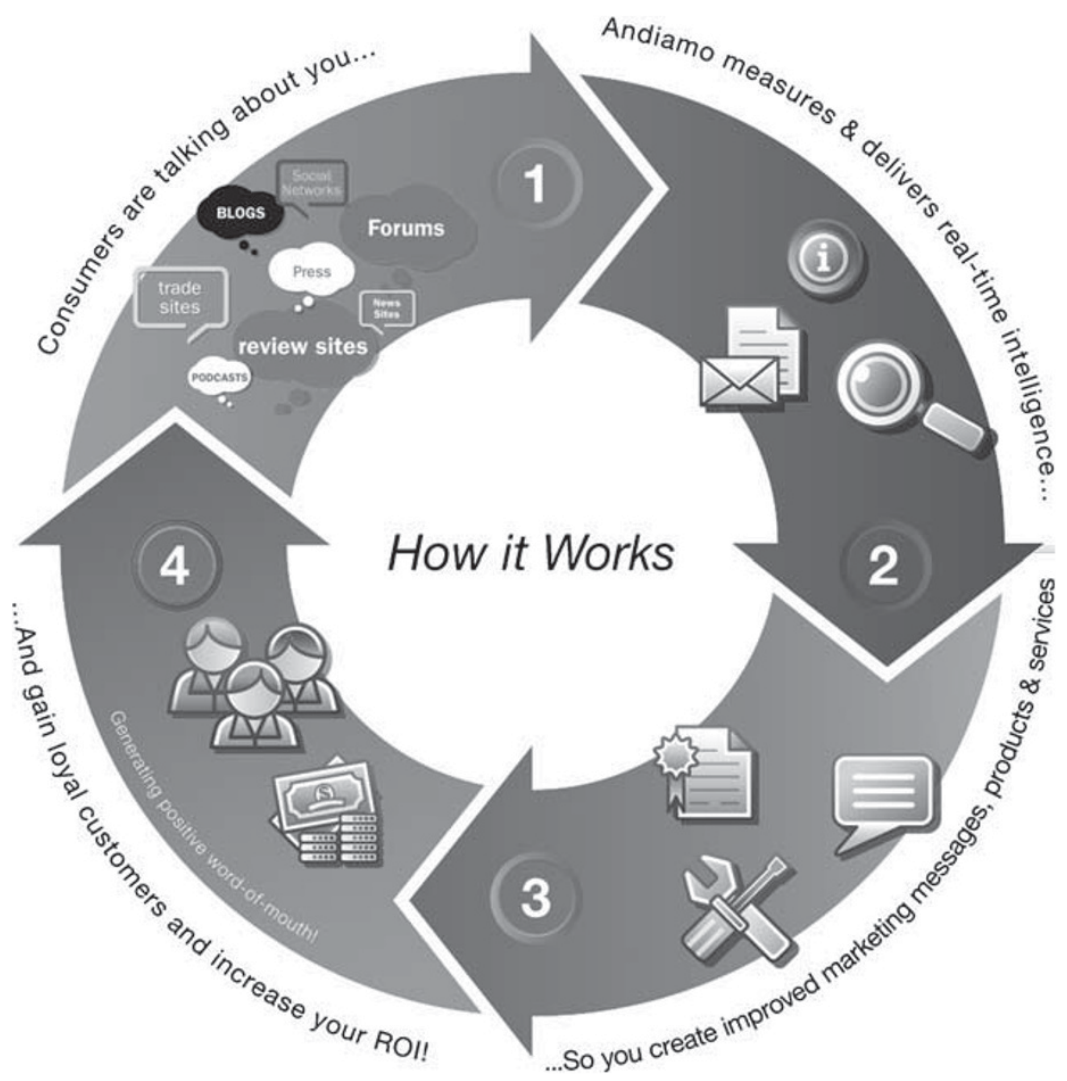

Figure 2: Social Media Flow. The social media flow as envisioned by Andiamo System's CEO John Hingley

MM: I'd like you to speak to - again, as a practitioner and as an innovation leader.

You've said that you're now able to monitor the conversation in a market. One of the things that this feedback loop that you've now provided entails is thinking not in terms of bigbang launches, but in several if not many soft or micro launches. They're almost conditional value propositions and conditional offers, based on what's getting traction. Did I get that right?

JH: Yes, you did.

MM: As marketers are beginning to rethink the very nature of a value proposition as being more of an open-ended collaborative conversation, as opposed to a fiat or a dictate of "Here's what it is..." How have you seen customers - users of your technology - take the insights in terms of the voice of the market, the voice of the customer and the voice of the brand? How have you seen them take that feedback and one: change the product offer, and two: change how they interact with customers?

JH: Sure thing.
Well, from one side of the spectrum you have the completely consumer-driven approach that Heinz 57 launched about six or seven months ago, called, “Top This.” They invited consumers - users of their product - to put together a 30 -second video commercial hosted on YouTube with - of course - the winner getting their commercial aired during the Daytime Emmy Awards. And, I believe, a $\$ 50,000$ prize. Of course you have some runner-up prizes and the like.

They received more than 5,000 entries of 30 -second clips. They allowed people to vote on the best one. They also took some of their own needs into account. They used consumers to basically deliver their entire campaign. That's pretty major.

The flip side... We have an insurance company that's always trying to break through the clutter of the boring insurance agency speak and offerings. They actually use us to mine what people are saying online about insurance as a whole. Different types of insurance. Their competitors and themselves. They're big believers 
in short YouTube videos using humor.

Sometimes tongue-in-cheek humor. Sometimes over-the-top humor.

They'll put these videos out every few weeks. They launch it with a little bit of promotion around the video. They've got a database and they've got some folks they notify by e-mail. But mainly it's just through YouTube.

They like to find out how people find a video. Where they come from. What they comment on. If they pass it along. What the pickup is. The overall impression of the short video.

They take this data and roll it back into all forms of their marketing and advertising campaigns: radio, print, interactive - even local television. They're doing the small screen and getting feedback so that they know what their marketing and positioning should focus on and what the hot buttons for consumer are.

The rapidity with which you can get this feedback is changing not just their marketing, but changing their business. They're able to be extremely relevant in what is perceived as a stayed industry. It's actually a very fast-moving industry as far as chief concerns.

They have issues across different types of insurance. It's really a very considered purchase. I think they have one of the most intelligent and cutting-edge ways of using viral video to help them create their overall advertising strategy.

MM: That reminds me of a conversation I had with another practitioner. Specifically around the uses of viral video and what makes it so juicy, compelling and effective.

In this conversation that we had late into the evening, there was a theme that developed. That was that most market communications in today's market strike most customers as boring, dull and irrelevant. You could call that lack of creativity, but it also reflects the growing discrimination and discernment that we as consumers apply to our media consumption.

As a function of that, most advertising really fails to connect with the consumer on a basic emotional visceral level. Specifically, not just hitting at the level of the six-year-old logic of the child within us. It's not entertaining and it's not fun.

So as we begin to think through the notion of viral video - specifically tracking its effectiveness or pass-along in various demographic cohorts - basically pass-along in repeated viewing seems to demonstrate that there's something attractive and engaging about that particular instance versus another instance.

So really, in many respects, viral video becomes part of the ideation process for what creative really connects with various aspects of my consumers or various segments of my market - be it consumer or B2B. That really provides the missing piece or link between effective creative and the kind of increased revenue that marketers now demand for their marketing investments.

Does that make sense? Do you have any data or anecdotal stories that support or modify that particular anecdote or finding?

JH: It is interesting. As a direct marketer for years and years - and that means going back to direct mail because that's about all there was we always had an adage which was, "Test before you invest." So we were always taking 20 or 25 per cent of our marketing budget and testing offers or testing headlines or different outer envelopes. It was Direct Mail 101.

MM: You called those Test Panels. Right? JH: Test Panels. Exactly. We'd test four or five different elements in any single major campaign that would go out. So we could continually roll into that next winner - whatever that winner might have been. But it's such a time-consuming process.

Creating all of these panels, printing, lettershop, postage, mail, third-class mail takes you three to four weeks once it goes out to get statistically valid numbers and results back. Then you have to bring that back in to creative and revise it based on the winning test panel. Then you go back through that entire process. It's all we had at the time. That means months before you can actually reap the rewards of the winning test. Who know? At that point some external force could affect things that render that winner moot.

Now, people want stuff when they want stuff. Consumers are in control. They'll go looking for product information when and where it is most convenient for them at the time. And their perceptions and needs can change quickly. Direct mail is not going to address those issues. That doesn't mean direct mail should disappear by any means. What it does mean is that 
businesses need to embrace social media as an additional channel to interact with consumers. Whether it's video or blog content and just articles and stories, the shift is very important. Once again, it's the companies that see this as an opportunity versus a threat that are - of course - getting the biggest benefit of it.

From a viral video perspective, in using a series of viral videos to achieve what direct marketing and direct mail testing did eons ago, I'd have to say our insurance client is the most sophisticated user of putting out the short viral videos to gauge consumer reaction within days or sometimes within one day.

MM: It makes complete sense that an insurance company would probably steal the march in terms of that particular activity. They understand actuarial tables. That means they understand statistics and econometrics. They believe in blazing spreadsheets.

Also, there's a very direct correlation between their marketing spend and premiums written six or eight weeks later. So it makes a lot of sense that they have a mindset already predisposed to closed-loop, analysis-driven marketing communications.

JH:Very well put.

MM: This also gives rise to another phenomena I'd like you to speak to. In fact, we have an executive briefing at the upcoming MOM and DAM Symposium on this. We call it Agency 2.0. The idea is that agencies must undergo a fundamental structural transformation from a creative services shop or boutique into a digital services platform by which to provision not just content, but to provision interactive services into the brand interaction of a client's engagement.

So agencies must make a shift from being artisans with lots of creativity to being very creative technologists about how to create more fluid content - and, more importantly, how to provision services into the brand interaction.

In our conversation and our investigation of that, one of the things that has loomed large has been the emergence of the social media agency. Specifically, the agency that really understands optimization strategies for social media - using metrics and really good, high-level analytics for not just driving the certain vehicles of social media be they viral newsletters or viral video - but informing the broader media mix optimization, in terms of what broadcast and print ads actually get traction with our particular target markets.

Could you speak to the notion of a 2.0 agency as a technical services platform? And perhaps conversations that you've had with next-generation marketing service firms or advertising agencies?

JH: First off, you are completely accurate. As a case in point, I believe Epsilon Interactive announced today that they changed their name. We of course all know that changing a name doesn't necessarily change the culture or the way it's operated. But they changed their name from Epsilon to Purple@Epsilon.com. The issue is, it's like United Airlines launching Ted. Unless the culture and direction changes along with the new name, it's like putting lipstick on a pig.

The stated reason behind this change was that they were getting concerned about market share loss to folks like Digitas, which is definitely more of a platform player. Folks like Digitas and newer agencies like IgniteSocial Media.

MM: Digitas, by the way John, is a great example of a traditional direct marketer that got down with interactive services and interactive promotions. It changed its name to Digitas about four or five years ago. Right? Then they ultimately sold out to - I think - WPP or Interpublic for $\$ 1.5 \mathrm{bn}$.

JH: That's right. I believe it was Publicis Groupe. MM: So they used a technology platform and a technology strategy as a value-creation driver for their exit plan. Thereby, it wasn't just about delivering great services to clients. It wasn't about speeding up time-to-market. Rather, it was about creating new wealth as a function of harnessing these new technologies.

JH: Fair enough. And it worked for them. MM: Absolutely.

Using that as a frame, could you speak a little more about how some of the traditional marketing service providers such as Epsilon and Merkle and Axiom and those kinds of companies are now looking at social media and more specifically, social media tracking - as a way to get back in the game?

JH: I think they realize it is vital for them to get a better understanding of it if they want to remain competitive. From what I've seen, these types of companies can be pretty slow to move though. They will probably acquire the talent and services via acquisition. 
MM: As I understand it, John, a lot of these companies - Epsilon being one of them were essentially database compilers. They would take magazines or associations or transaction records from companies into their big mainframes.

Then, they started compiling other kinds of information, like credit information or household information or business information. They really became sources of data enrichment in terms of "What else do we know about John Hingley who lives in San Francisco?"

A lot of these systems or companies Epsilon and so on - started developing database marketing and direct response service capabilities by which to harness the data that they had plans to maintain and compile.

Now they're addressing the fact that that's just one part of the mix. The real growth is not necessarily in direct-response marketing, per se, but it's how we manage the engagement and interaction with customers with direct response being one aspect of the overall engagement. Is that a fair summarization?

JH: It's a great summarization. The way these traditional Epsilons of the world see social media is that it's a huge opportunity for them to build upon their service offerings, maybe reposition their brand and become more relevant to a lot of today's potential customers. They may also take a wait-and-see approach though. See what shakes out in terms of players, metrics and overall market size of word-of-mouth. The market is sized at right around $\$ 1 \mathrm{bn}$ currently, which may not be large enough for some of these guys to take action on.

But also, just like myself, coming from a direct marketing numbers-and-metrics standpoint, and knowing that metrics are in a huge flux right now. No one really knows how to measure engagement, but everybody's trying to give that some type of definition.

Being very acutely aware that traditional direct marketing, and even advertising metrics, are becoming if not less relevant, then challenged by some of the newer types of metrics such as engagement. They see this as an opportunity to build on something they already have.

As you mentioned, Michael, it's a prowess in gathering information to help companies make better decisions. I've always been a believer that social media analysis - analyzing what's going on with Facebook and MySpace or any blog out there - is an integral part of an overall marketing strategy or marketing offering for an end-user or client. Warner Brothers, Fox Television, Sony, Intuit or whoever it might be.

So the agencies see - I believe - an opportunity and, really, a necessity to have some type of offering or expertise in the social media area. To be more holistic in their offering and their understanding of the customer. And to be able to keep current clients and attract new ones.

We speak with agencies every day. Of our client base, I'd say that 40 per cent are agencies. They deliver about 80 per cent of our business. They're acting out of two primary motivations. One is a true understanding and appreciation of social media. How to use social media to costeffectively build a brand and keep it relevant and buzzy out there over time.

The second motivator is the individual brand owners. The CMO at Coke or the VP of Marketing at Warner Bros are getting educated on the values of social media. So agencies need to become pros in this area as well or they risk losing business. I hear this from agencies repeatedly. They feel a threat of not being that traditional "expert" in all areas of advertising. Social media in some ways levels the playing field. So small, focused agencies can compete with big ones because now they're the experts in social media. Agencies feel that even if they don't know exactly what to do with social media, and how best to drive benefit for their clients, they at least need to start with a monitoring and measurement system. Because they know they at least have to listen to what's being said online and be able to integrate that in with other pieces of their campaign planning. Or, as you mentioned before, their media planning.

Within an agency, there are two primary users from our perspective. One is account planning. One is media planning. Helping the media planners allocate budget toward the appropriate venues. Offline and online.

The second is account planning. How to use this newly available and readily available information online to have a better success rate in client pitch-to-win ratios. So it's actually using this ahead of the curve during a client pitch phase. 
MM: Actually, you're really talking about three functions. The media planning is usually the caboose. Right? That's putting together the online/offline media mix in terms of "Given these objectives and given these demographics, where do we best spend the money." Right?

Account planning is not just about account services, but what projects to pitch and sell hard as opposed to pitching more tentatively or prospectively. Right? But that's all about managing an existing account.

The third that you've just called attention to is really new business development. Oftentimes it's the insights supported by the analytics and more specifically, the social media analysis - that justifies breaking out of my agency of record relationship and going with a small interactive shop. Because they've got the data to support doing this, and they've got the feedback loop to measure its effectiveness.

You're saying that this tight, fast-cycle closed loop that social media analysis provides gives the smaller, nimble, hot interactive shop not just parity, but an unfair competitive advantage by which to start stealing most of the upside growth in an account.

JH: I'd say that's a fair assessment, yes.

MM: There is another thing that kind of falls out of this whole thing. Fundamentally, as we start to get better and better data in terms of "who's consuming what" as a part of our message, this comes back and changes the ideation process for creative. I think we've covered that.

I'm interested in understanding this from an agency perspective or agency business model. How does that ripple into more of the account planning piece, and ultimately the sourcing? All of a sudden now, agencies have to not just source from a bunch of local creative boutiques or creative subcontractors, but oftentimes across the globe. Be they in Singapore, Australia or Amsterdam.

Can you speak a little bit in terms of how social media analysis and social media tracking is not just about how to spend money more effectively in my domestic market, but also international ones? Social media knows no bounds. Right?

JH: True.

I'd point to a new agency called Alt. I believe the URL is ThinkAlt.com. They take a true cross-functional view and approach to social media analysis. We have been in very close conversation with these folks at the use-case level of our services. They have many. Although they're brand new, they all come from other agencies, and they left to start this new agency that was an alternative - just like we've been talking about - [to] the traditional agency. Using new types of media, new thinking and new tools such as ours to help them do a better job for their clients - and, of course, win more business overall.

It may sound more simple than it is. It's easy to say that you're going to set up a global or at least a shared media buy or media planning group within your agency. Most large, entrenched agencies can't move that quickly.

Alt is in the process of perfecting something for which they definitely have the right culture and plans in place. They have a few big clients that they actually perform some global campaigns for. Number 1 - the most simple they make sure that every regional, domestic or international client has been in the same conversation with us about the use of our services. They go into the planning mode ahead of even using it, with a strategy on the communication and use and responsibility of using the data that we provide them.

I think it's more cultural and organizational versus any type of necessities to change platform. Some of the things I'm seeing in most agencies - especially ones that have been around longer than others - are similar to about any industry type. Whether it's Mattel or a smaller company. The more you grow and the more tenure your business has, the more you typically silo and become more challenged to respond quickly and efficiently to new technologies and customer needs. You get stuck.

That's hard to break out of. I've seen agencies say they're going to do this, and they'll share information across functional groups. That always needs to be done - but also with regional groups inside and outside the US. It just doesn't transfer.

Goals aren't aligned. Roles and responsibilities aren't aligned. It's my best guess that Alt has a real advantage in starting with a blank slate. MM: Not just a blank slate, but a completely different mindset.

JH: Exactly. In some ways like me with my experience. They've seen the mistakes in 
agencies. They've seen the good things. I think they know when to zig and when to zag much better than they ever have in their careers. They also have the flexibility all the way up.

This is a company where the president of the company is the number one believer in the use of, importance of and measurement of social media. So it's coming all the way from the top down. The people he's brought on are as enthusiastic and passionate about social media as he is. It's more of a cultural phenomenon and an organizational one than anything else. So, clear lines of responsibility and a sharing type of environment that doesn't exist in a lot of traditional agencies. That's the biggest difference.

I had a boutique agency. I wasn't a WPP or a Publicis or anything like that. But knowing many, many people in companies like that, I think that the best chance they have of achieving what you mentioned - a more global understanding and use of this data to do better media planning would be to either start a new group focused just on that, or acquire a company that already has that as part of its culture.

MM: That's the big argument that's going on right now. Right?

A lot of the mainstream agencies have a print-and-broadcast body, and they've got a digital arm. Right? The conversation is, should you have a digital body with a print-andbroadcast arm. Right?

JH: Exactly.

MM: This actually reminds me - eerily - of how television disrupted the agency business in the 1960s. Before the 1960s and the massadoption of television you had large, old-line agencies: BBDO, Ogilvy \& Mather, Young \& Rubicon. They'd been around really from the automotive industry and/or the packaged goods industries that grew up in the 1910s and 1920s. They were primarily a print shop. They did print, magazine, glossy four-color display ads and newspaper ads - with a little bit of outdoor and a little bit of in-store packaging. But primarily they were print shops.

Television came along and it completely disrupted the marketing value proposition. About a third of those old mainline agencies made the transition. We still know them today as OgilvyMather, BBDO and so on.

About a third of the agencies retreated into becoming strong shops for regional retail chains.
Leo Burnett would be a great example of just somebody that "got" television. Right? They made it their culture. Really to say, "We are going to build brands around broadcast spots and great storytelling."

We're seeing that same kind of disruption today. There'll be about a third of the mainline agencies that make the shift. And a couple of those are going to be probably Publicis and WPP. They really get the notion of a digital corpus. They get the notion of a digital services platform.

Publicis is most remarkable in that their CIO is driving a six-sigma-like methodology into all of their IT services. It's called, "CMMI." Capabilities Model Integration.

It's the same process methodology that all of the Indian outsourcing firms use to deliver their enterprise solutions. That allows companies like KATA consulting services to make the outrageous - but nonetheless substantiated claim that we can deliver ERP to global enterprises on time, at budget and 96.4 per cent of the time.

That's a really rigorous management process control framework. Those agencies - the Publicis and WPPs are probably going to make the change. That really calls attention to the fact that a certain number of these mainline agencies today are simply not going to make the transition. They're not going to give up their print-and-broadcast core and shift basically to the fast-cycle, analysis-driven methodology that we've been talking about today.

There'll be another third, five years from now, that will just kind of rocket out of nowhere. Like AltThinking. Companies like that will be the next Leo Burnetts of the Web 2.0 world.

This calls attention to something that you and I were again alluding to or getting into a little bit earlier - in terms of the dubious tenure of many CMOs today. Specifically, many CMOs today do not get digital interactive. Nor do they get social media. They just don't. It's not in their body. They haven't had experiences of it and so on.

That suggests that over the short-term of this next two or three years there's going to be a career fast track to a senior director or a vicepresident of interactive or a vice-president of social media that's a function of all of these good analytics that drive the ideation process. 
That drive the voice of the brand through a series of soft launches. It will ultimately have the data by which to optimize the entire media mix. It will be able to think through the execution of a strategy as an analysis-driven engagement.

Can you speak to the notion of the career track that social media analysis now starts to light up and/or open up?

JH: First off, just over the past year, go to LinkedIn or ZoomInfo and do a search on "job title" including social media. A year ago, if you would've gone in and done a search on peoples' job titles with social media as part of their title, I can almost guarantee you'd've gotten a handful of matches at best. There just wasn't any type of sole responsibility or authority. Now, social media planning, social media evangelist, social media marketing director, etc are all very hot positions in more forward-looking companies big and small.

If you go do that search now, actually "Social Media Manager or Director of Social Media" is a pretty popular title.

That's a really telling shift. I don't think this is a passing fad. I'm not a big fan, overall, of too many C titles. Like Chief Revenue Officer, Chief This Officer. Chief That. I think some of those were born out of the dot-com era.

But when I see as many social media analysts and social media evangelists - just the breadth of titles and the number of folks that have that - not just as part of their responsibility, but their sole responsibility due to that job title... It's actually staggering.

That means it's turning from a part-time hobby to a crucial element of the business. I believe that positions people that are at the forefront of this space as being uniquely qualified. As you mentioned, in a very fast-track fashion. Maybe being at one firm or agency for a couple or three years, and probably leaving that company when they get opportunities two or three levels up in a different company - just by virtue of having that much focused experience and capability under their belt. MM: If I was looking to hire a "Social Media Manager," tell me what I should look for in terms of experiences and capabilities. What should their résumé look like?

JH: Good question.

I do think that experience at either an interactive agency or experience with work at the client or brand level — at the VP level and being very involved in interactive marketing would be key. I've seen that you've got your print people and you've got your television people. You've got your this people and that people.

Folks that actually come from and have exhibited experience and skills on the interactive side will come into the picture with a much greater understanding of at least the potential ways of using social media analysis to help drive multichannel promotion. Also, just the knowledge of "Hey, here's how we can leverage Facebook for this promotion." So it's also practical uses of social media to drive market awareness and campaign impact in an ongoing fashion.

That's something that you brought up a bit ago that I didn't touch on. There's the shortterm focus versus the longer-term. "What is word-of-mouth and how is word-of-mouth around your brand over the long-term?" versus just the little spike that you used to get after a televisison commercial or a radio spot or whatever it might be. So, interactive marketing would be a chief one for me.

Additionally, working with global brands. As you mentioned, social media knows no boundaries. It's everywhere. Having someone with true global brand experience.

Also - and this may be a bit biased - I do believe that folks I've seen actually make some of the best use of this data, at least understanding the data - do have some direct marketing or database marketing experience... how to actually put the data to effective use and drive measurable results.

MM: Couldn't agree more.

Here's what I would suggest - they've personally overseen, managed or were part of a group that generated more than $\$ 200 \mathrm{~m}$ of revenue through mobile phones. So they understand the customer or user experience from a mobile device perspective.

They also will probably have their own blog. And have a fan club and following.

Another thing they'll have, aside from all of the straightforward, direct-response database marketing analytics piece and its sister or adjacent category of "Marketing Analytics," which is surveys and all of that kind of standard stuff - focus groups and use of syndicated research... They will have a very deep 
grounding in web analytics. Specifically, what do traffic and hotspots and websites mean? How to listen with data. Then, to take that data, whether it's traditional customer insight and marketing analytics, database marketing analytics or web analytics, and convert that into creative briefs and content strategies.

Both content strategies on my side of the firewall as well as dynamic messaging in terms of push or things that are outside of the firewall.

It seems to me that this person should probably have, if not a practitioner's

understanding, at least an adjacent one. "I'm really familiar with it, but I haven't done it" kind of understanding of content optimization. That is, metadata, tagging, XML schemas and how we light stuff up not only for it to be found in search engines and be highly ranked, but how we create and engineer a page from a contentmanagement, content-optimization page so that we're cross-linking and cross-indexing and making that page super-sticky from assets that we own and control in our content-management or in our editorial operations system?

It seems to me that we're talking about a fairly rare bird. Right?

JH: If I mined through all of my contacts there might be a small handful of qualified people.

MM: The last one - this is the one that I think will end up being the vice-president or executive vice-president of social media for the AmExs and the Toyotas of the world. It'll be somebody who understands that analytics is no longer just advanced statistics, but actually constitutes applied game theory.

They'll probably have, if not a Masters, a $\mathrm{PhD}$ in game theory. They'll understand that brand interaction constitutes an application of game theory. That puts emphasis on eliciting truthful information at progressively deeper, more intimate levels. Then correlating that into almost a theatrical production. A brand theater that allows a self-directed customer or a self-directed stakeholder to engage in and fulfill some sort of self-service.

JH: Ha. The list just got shorter!

MM: But the very short list becomes the CMO of AmEx. Right?

JH: Bingo.

MM: As we wrap up this interview, are there any kinds of forward-looking things that you anticipate in the next 18 months or so?
JH: I think that the ability for consumers to actually — in addition to just commenting give their opinions on things. Movies, books, food and wine. Where possible, smart companies and their agencies are going to involve the customer in the actual content. Write your own ending to a book or film or what have you. To really use consumers' insights. Not just as an opinion panel, but actually as more active participants in content, product and ad creation.

Right now you have things like the Heinz 57 "Top This" campaign. I thought that was a great promo. I think that Pepto-Bismol television commercials are just awful. They've got five or six people up there - one person mimicking an upset stomach, one diarrhea. I have no problem with the content. But that to me is not a creative or even an effective way of using consumers in your media. It's really involving them in ways that are engaging, and not scripted. I think that Heinz did a very good job. I think that our insurance company unfortunately I'm under NDA with them so I can't give you their name - is doing a great job at least at this stage of just getting the feedback. It's going to be involved more, going forward, with consumers.

This is something we didn't touch on and we probably don't have time to. But there's the whole argument of the value of influentials. Right? In order to keep that buzz going - that market awareness - that positive word-ofmouth going. It's engaging with the influencers in each little mini market niche. Sometimes they're not mini market niches. Sometimes they're large ones.

Really engaging with these people in transparent, mutually beneficial ways to harness the power of these folks to help build consumer opinion. That's number one.

Secondly, from more of a tool and analysis perspective, I see a lot more of what we're doing. A lot more flexibility in how you use the information and intelligence that we provide.

From either an agency workflow process of "How do we get through APIs, through better understanding of each other's needs, to allow our information to flow right into your existing reports that you put out?" If you're Overture or WebTrends or someone who was already providing - as you mentioned - web analytics intelligence... How do we make it very easy for 
your customers to also access everything going on outside of the website that Overture or WebTrends is analyzing for you?

If you want to bring other data into our application and have that be reported on a sideby-side basis... if you want to overlay campaign data and budgets and happenings right on top of reports so you get a real holistic understanding of cause-and-effect of ad dollars spent on word-of-mouth growth and increased brand perception. Those types of things.

I think there are more ways to make it easier. As this mountain of social media grows, there are more ways to allow companies and their agencies to effectively respond to and organize all of this content - to maximize the value of it.

We're early on in this market. It's just so powerful to companies that we're able to find it all and analyze it all and give it to them in a nice suite of web-based reports. But it's got to go beyond that. It's got to solve a bigger issue. It's got to be more manageable and more integrated with other established or soon-to-be established marketing dashboards or campaign reporting.

MM: John, this will perhaps serve as the coda for our next interview. One of the things that we've begun applying is an information maturity model to marketing operations. It was initially pioneered, I think, by SAS. Now it's beginning to take an open-source life of its own.

The idea is that if you look at a maturity model like any maturity model, it goes from no structure and no management to things that are dynamic and closed-loop. You go from just data to standard reports to descriptive modeling, predictive modeling, and then the nirvana, which would be real-time adapting.
As you start talking about how the social media data or the social media analysis becomes part of a larger set of metrics, almost inevitably what you run into is the relative immaturity of most marketing organizations as users and managers of data of information.

Fair enough?

JH: There are very few defined metrics right now, but it's going to change quickly. The biggest challenge is to define and develop "standards." We all know how long that can take. So we'll start seeing companies such as Andiamo Systems and others - probably large agencies as well - develop their own metrics and marketing dashboards. Over time these metrics will being to become more standard, but it'll take a while.

MM: I think in terms of an overall industry that calls attention to the fact that part of what vendors such as yourself - and think-tanks such as us - really have to do is to start educating those that are on this fast track career path to becoming the CMO vis-à-vis the social media route. That they really start to understand the importance of managing information processes. Not just managing information, but managing information processes.

That takes real infrastructure, real investments and a maturity that's going to take some companies a long time to develop. Some, with the right mindset, will be "Oh, yes! Fine! That's what we need to do. Let's go do it."

JH: Yes.

MM: Again, I want to thank you for interacting here with us in the interviews and for the points that you've developed.

JH: Outstanding. I appreciate your time. MM: Absolutely. Thank you. 